\title{
Pengembangan bahan ajar media pembelajaran fisika dengan pendekatan multi representasi untuk mengembangkan kemampuan pembuatan alat-alat praktikum fisika
}

\author{
Chandra Sundaygara *), Hestiningtyas Yuli Pratiwi, Muhammad Nur Hudha \\ Program Studi Pendidikan Fisika, Universitas Kanjuruhan Malang, Indonesia \\ *Penulis korespondensi, e-mail: chandrakirana@unikama.ac.id
}

\begin{abstract}
Regarding the lack of physic material in teaching, the aims of this study was to develop physic instructional teaching material. The teaching material was electric and magnetic teaching based on multi-representation. Four-D (Define, Design, Develop and Disseminate) proposed by Thiagarajan, et al, 1974 was applied to know the development of the ability to design and assemble physics experimental tool. Furthermore, this paper also depicts the students' responses toward the teaching material through questionnaire. The major data were validity and feasibility test result done by expert validator. The findings showed that the mean of feasibility test was 3.51. It means that the test was valid. Therefore, the material was feasible to be applied. Students' responses of the limited trial toward the physic teaching material -multi representation based- obtained the average value, 3.58 . The value means that the feasibility of the trial was categorized as valid.
\end{abstract}

Key Words: Physics learning media; Multiple representation; Teaching Materials

\begin{abstract}
Abstrak: Tujuan penelitian ini adalah untuk memperoleh bahan ajar media pembelajaran fisika berbasis multi representasi untuk mengembangkan kemampuan membuat dan merangkai alatalat percobaan fisika dan mengetahui kelayakan serta respon mahaiswa terhadap bahan ajar ini pada materi listrik dan magnet. Metode penelitian ini adalah penelitian dan pengembangan (R\&D). Desain penelitian menggunakan desain Four-D yaitu Define, Desain, Develop, Disseminate oleh Thiagarajan, dkk., 1974. Instrumen penelitian adalah angket. Data penelitian terdiri dari data uji kelayakan oleh validator dan data ujicoba terbatas yang diberikan kepada mahasiswa yang diperoleh melalui pemberian angket. Hasil penelitian menunjukkan bahwa: (1) Uji kelayakan yang didasarkan validasi ahli media dan ahli materi diperoleh nilai rata-rata uji kelayakan sebesar 3,51 yang dikategorikan baik/valid sehingga bahan ajar layak digunakan, (2) Respon siswa terhadap bahan ajar media pembelajaran fisika berbasis multi representasi melalui ujicoba terbatas diperoleh nilai rata-rata ujicoba terbatas sebesar 3,58 yang dikategorikan baik/valid
\end{abstract}

Kata Kunci: : Bahan Ajar; Media pembelajaran Fisika; Multi Representasi

\section{Pendahuluan}

Media pembelajaran mempunyai peranan yang sangat penting dalam pembelajaran Fisika. Media pembelajaran mempunyai peranan dalam proses pembelajaran karena digunakan sebagai alat untuk menyampaikan informasi atau pengetahuan dalam pengajaran (Arsyad, 2010); (Basyarudin Usman, 2002). Penggunaan media pembelajaran akan dapat meningkatkan pemahaman siswa terhadap materi yang dipelajari (Sutikno, 2013). Penggunaan media pembelajaran akan membantu siswa mempelajari konsep-konsep fisika yang bersifat abstrak menjadi lebih

How to Cite:

Sundaygara, C., Pratiwi, H., \& Hudha, M. (2019). Pengembangan bahan ajar media pembelajaran fisika dengan pendekatan multi representasi untuk meningkatkan kemampuan pembuatan alat-alat praktikum calon guru fisika. Momentum: Physics Education Journal, 2(2). https://doi.org/10.21067/mpej.v2i2.2709 
nyata/konkret. Media pembelajaran dalam pembelajaran fisika lebih terkait dengan alat-alat percobaan/praktikum. Oleh karena itu untuk dapat mengoptimalkan proses pembelajaran, seorang guru harus dapat menggunakan bahkan harus dapat merancang, dan membuat media pembelajaran apabila media pembelajaran belum tersedia. Akan tetapi, hasil penelitian yang telah dilakukan terhadap kemampuan guru dalam merancang dan menyelenggarakan kegiatan praktikum fisika di sekolah menengah, ternyata belum optimal (Utari, 2010);(Gunawan, 2010). Hal ini disebabkan antara lain tidak tersedianya alat-alat praktikum dan guru kurang kreatif dalam mengembangkan peralatan alternatif yang dapat digunakan untuk melakukan percobaan/praktikum.

Didukung dengan hasil wawancara kepada mahasiswa pendidikan fisika angkatan 2014 Universitas Kanjuruhan Malang yang sebagian besar berasal dari NTT dan NTB diperoleh data bahwa percobaan/praktikum jarang dilakukan dalam proses pembelajaran fisika disekolah. Hal ini dikarenakan tidak tersedianya alat-alat percobaan/praktikum. Ketidaktersediaan alat-alat percobaan/praktikum dialami terutama dialami oleh sekolah-sekolah mahasiswa yang berada di luar jawa yaitu sekolahsekolah di Nusa Tenggara Timur dan Nusa Tenggara Barat. Oleh karena itu, calon-calon guru harus mempunyai keterampilan dalam membuat media pembelajaran berupa alat-alat percobaan/praktikum.

Keterampilan pembuatan media pembelajaran calon guru dikembangkan dalam mata kuliah pengembangan media pembelajaran fisika. Melalui perkuliahan ini, calon guru akan dibimbing dalam pembuatan media pembelajaran berupa pembuatan alat-alat percobaan fisika. Dalam membuat alatalat percobaan, mahasiswa masih fokus dalam pembuatan alat-alat percobaan untuk konsep-konsep fisika yang sederhana seperti alat percobaan bandul sederhana, hukum hidrostatik, hukum pascal. Sumber informasi untuk pembuatan alat-alat percobaan/praktikum berasal dari informasi dari intenet karena belum tersedianya bahan ajar/buku tentang pembuatan alat-alat percobaan/praktikum. Oleh karena itu, diperlukan bahan ajar yang dapat digunakan calon guru sebagai panduan untuk merancang alat-alat percobaan yang telah tervaliditas yang dapat mengembangkan kemampuan pembuatan media pembelajaran calon guru fisika dan sebagai sumber belajar pada mata kuliah media pembelajaran di Universitas Kanjuruhan Malang. Bahan ajar akan dapat memberi kemudahan kepada peserta didik/ mahasiswa dalam upaya memperoleh sejumlah informasi, pengetahuan, pengalaman, dan ketrampilan dalam proses belajar mengajar (Toharudin dkk, 2011).

Bahan ajar yang dikembangkan adalah buku ajar tentang pembuatan alat-alat percobaan dalam konsep-konsep fisika. Bahan ajar yang dikembangkan tidak hanya dijelaskan tentang bahanbahan yang dibutuhkan dan penjelasan tentang cara membuat, akan tetapi langkah-langkah pembuatan alat percobaan/praktikum yang disajikan menggunakan pendekatan multi representasi. Tata cara pembuatan akan disajikan dalam representasi verbal dan representasi gambar. Penggunaan multi representasi akan meningkatkan pemahaman mahasiswa dalam pembuatan media pembelajaran. Menurut hasil penelitian (Rosengrant, Van Heuvelen, \& Etkina, 2009) mahasiswa yang menggunakan representasi gambar dengan benar mempunyai kemungkinan menyelesaikan masalah fisika dengan benar. Hasil penelitian ini didukung oleh hasil penelitian (Astuti, 2012) yang menemukan bahwa penggunaan buku ajar fisika dengan pendekatan multi representasi dapat meningkatkan pemahaman konsep fisika siswa. Hasil penelitian menunjukkan bahwa buku ajar berbasis multi representasi merupakan buku ajar yang baik dan layak digunakan sebagai sumber belajar siswa (Silaban, K.S., Bakri, S., Delina, 2016). 


\section{Metode}

Jenis penelitian ini adalah penelitan dan pengembangan atau disebut Research and development (R\&D). Desain penelitian menggunakan Desain Four-D yang terdiri dari tahap tahapan Define, Design, Develop, dan Disseminate menurut Thiagarajan (S. D. Aji, Hudha, Huda, Nandiyanto, \& Abdullah, 2018). Pada penelitian ini, tahapan disseminate adalah secara terbatas yaitu uji coba dengan memberikan bahan ajar ke pada mahasiswa yang mengampu mata kuliah media pembelajaran untuk memberikan penilaian terhadap produk dengan cara mengisi angket. Prosedur penelitian pengembangan bahan ajar media pembelajaran berbasis multi representasi disajikan pada Gambar 1.1 (Hudha, Aji, \& Huda, 2018).

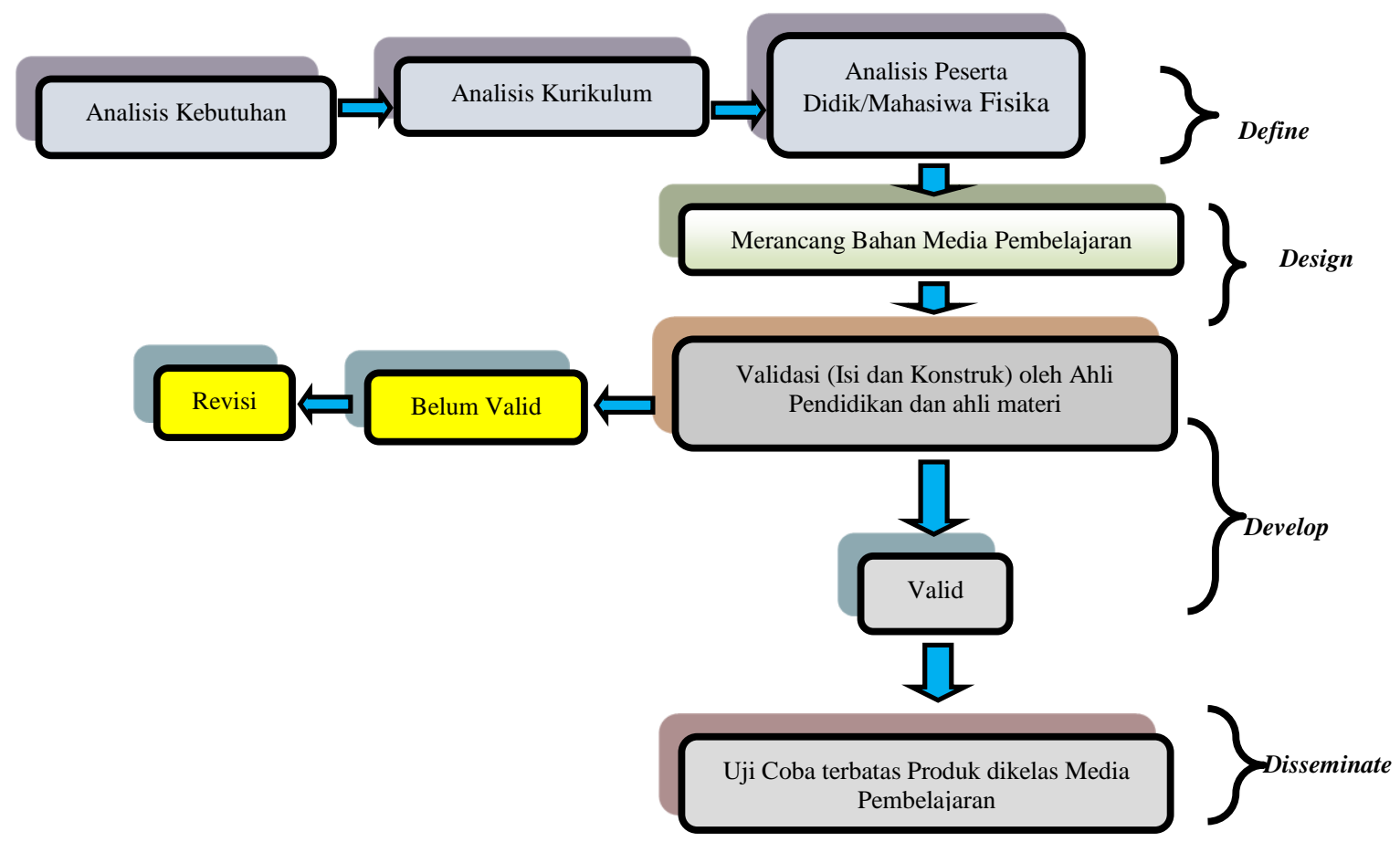

Gambar 1.1. Desain Penelitian Bahan Pengembangan Bahan Ajar Media Pembelajaran Berbasis Multi Representasi

Instrumen yang digunakan untuk mengumpulkan data pada penelitian ini ada 3 jenis, yaitu (1) Angket kebutuhan siswa, (2) Angket validasi produk, dan (3) Angket respon siswa.Data terdiri dari dua macam yaitu data kuantitatif dan data kualitatif. Data kuantitatif diperoleh dari angket dan data kualitatif diperoleh berdasarkan masukan dari validator dan mahasiswa pada saat ujicoba terbatas.

\section{Hasil dan Pembahasan}

\section{a) Produk Bahan Ajar Media Pembelajaran Fisika Berbasis Multi Representasi}

Bahan ajar yang dihasilkan pada penelitian ini adalah bahan ajar tentang pembuatan dan penggunaan media pembelajaran fisika berupa alat-alat percobaan/praktikum fisika pada materi listrik dan magnet yang meliputi sub materi rangkaian seri paralel, jembatan Wheatstone, medan magnet, induksi elektromagnetik, dan transformator.

Bahan ajar yang dikembangkan terdiri dari beberapa bagian antara lain cover, kata pengantar, daftar isi, materi dan daftar pustaka. Materi yang disajikan terdiri dari 3 bagian yaitu bagian pendahuluan, konsep/teori fisika, dan pembuatan alat percobaan. 


\section{1) Pendahuluan}

Pendahuluan berisi tentang aplikasi konsep/teori yang akan dipelajari dalam kehidupan sehari-hari yang disajikan dalam bentuk permasalahan yang dapat mengembangkan kemampuan berfikir mahasiswa. Situasi pembelajaran yang autentik berdampak pada kebermaknaan belajar sehingga memudahkan siswa untuk melakukan penemuaan (Sundaygara, C., Kusairi, S., Hidayat, 2014). Selain itu pemberian permasalahan autentik akan mengemangkan kemampuan pemecahan masalah mahasiswa yang akan berdampak pada penguasaan konsep yang baik pula (Stephens \& Clement, 2010). Permasalahan yang dimunculkan pada awal bab disajikan dalam bentuk multi representasi yaitu menggunakan representasi gambar dan representasi verbal berupa penjelasan. Penggunaan lebih dari satu representasi menurut akan memudahkan mahasiswa mempelajari konsep atau materi yang disajikan (De Cock, 2012). Contoh pendahuluan dalam bahan ajar disajikan pada Gambar 2

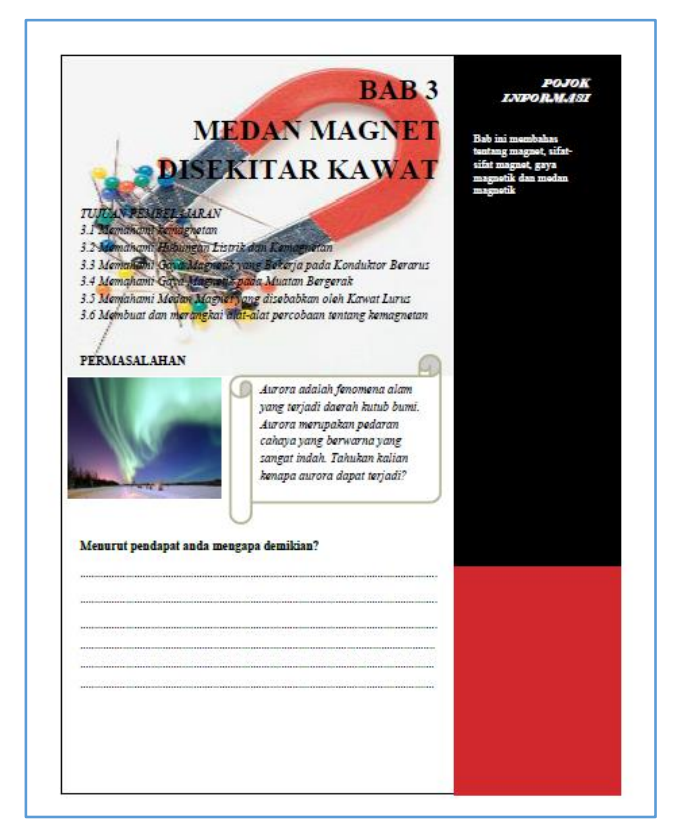

\section{Gambar 2. Isi Pendahuluan pada Awal Bab pada Bahan Ajar}

\section{2)}

Konsep/ teori fisika

Konsep/teori yang disajikan adalah teori/konsep fisika yang berkaitan dengan media yang dikembangkan/dibuat. Tujuannya agar mahasiswa mengetahui konsep/teori yang mendasari media pembelajaran yang dibuat. Pada bahan ajar ini teori selain berupa penjelasan (representasi verbal) juga dilengkapi dengan representasi matematik dan representasi gambar. Multi representasi mengacu pada penggambaran suatu konsep dan proses yang sama dalam format yang berbeda, termasuk format verbal, grafik dan format numeric (Tytler, Haslam, Prain, \& Hubber, 2009). Penggunaan multi representasi akan memudahkan mahasiswa memahami dan menguasai konsep fisika (Sundaygara \& Gaharin, 2017) Contoh penyajian konsep fisika disajikan pada gambar 3 


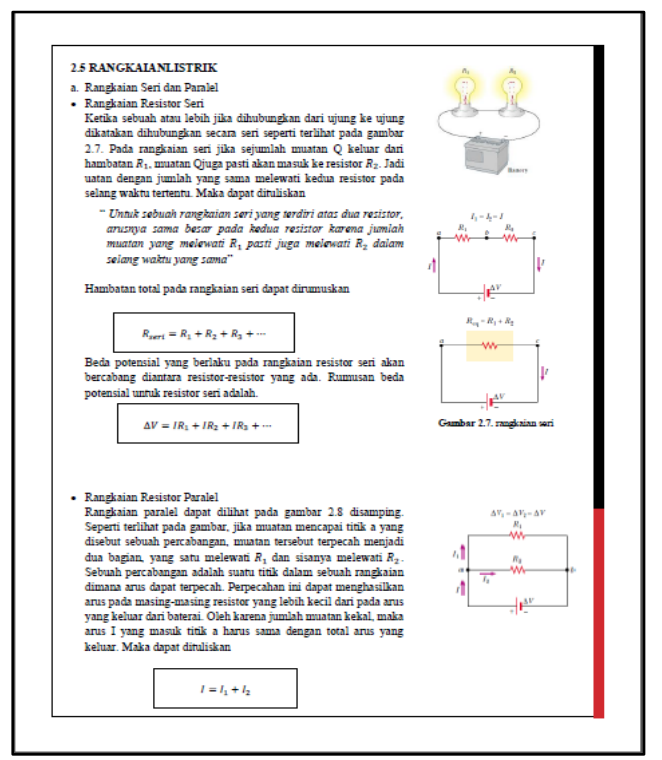

\section{Gambar 3. Penyajian Konsep Fisika Pada Bahan Ajar}

3) Pembuatan dan penggunaan alat percobaan/praktikum

Pada bagian ini disajikan alat dan bahan yang dibutuhkan, cara membuat atau merangkai alat-alat percobaan/praktikum. Cara pembuatan alat-alat percobaan disajikan dalam representasi verbal berupa penjelasan dan representasi gambar yang menyajikan foto tahapan pembuatannya. Penggunaan representasi gmbar akan membantu mahasiswa memahami materi atau penjelasan yang bersifat abstrak (Sundaygara, C., Kusairi, S., Hidayat, 2014) (Lovisa, 2011). Representasi gambar akan mempermudah mahasiswa memahami langkah-langkah pembuatan alat-alat percobaan fisika dan meminimalisir kesalahan ketika membuat alat. Contoh materi prosedur pembuatan alat percobaan fisika disajikan pada gambar 4.
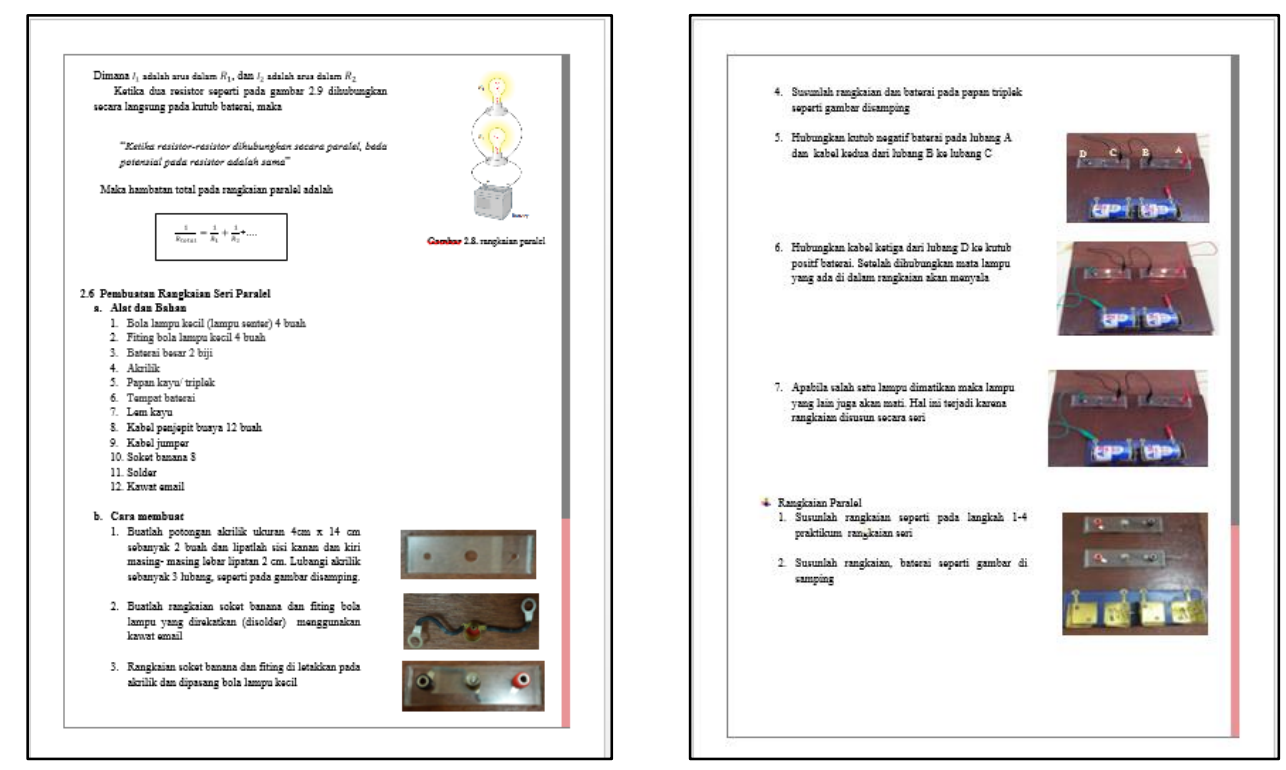

Gambar 4. Contoh Materi Bahan Ajar Prosedur Pembuatan bahan Ajar 


\section{b) Hasil Penilaian Produk Bahan Ajar Media Pembelajaran Fisika berbasis Multi Representasi}

Hasil penilaian produk bahan ajar media pembelajaran fisika berbasis multi representasi terdiri dari hasil uji kelayakan isi, uji kelayakan penyajian, uji kelayakan bahasa bahan ajar.

1) Data Uji Kelayakan (Validitas)

Data uji validasi terdiri dari uji kelayakan isi bahan ajar, uji kelayakan penyajian bahan ajar, dan uji kelayakan penggunaan bahasa dalam bahan ajar. Data uji kelayakan disajikan pada Tabel 1.

Tabel 1. Data Uji Kelayakan Bahan Ajar

\begin{tabular}{|c|c|c|c|}
\hline Keterangan & Rata-Rata & $\begin{array}{l}\text { Kriteria } \\
\text { Penilaian }\end{array}$ & Kategori \\
\hline \multicolumn{4}{|l|}{ Kelayakan Isi } \\
\hline Permasalahan yang disajikan & 3,50 & Baik & Tidak revisi \\
\hline Cakupan Materi konsep fisika & 3,50 & Baik & tidak revisi \\
\hline $\begin{array}{l}\text { Cakupan materi /Langkah-langkah } \\
\text { pembuatan alat percobaan }\end{array}$ & 3,50 & Baik & tidak revisi \\
\hline \multicolumn{4}{|l|}{ Kalayakan Penyajian } \\
\hline Tata letak & 3,50 & Baik & tidak revisi \\
\hline Warna & 3,50 & Baik & tidak revisi \\
\hline Gambar & 3,75 & Baik & tidak revisi \\
\hline Sampul/Cover & 3,75 & Baik & Tidak revisi \\
\hline \multicolumn{4}{|l|}{ Kelayakan Bahasa } \\
\hline Bahasa dalam penyajian masalah & 3,50 & Baik & tidak revisi \\
\hline $\begin{array}{l}\text { Bahasa dalam menjelaskan materi } \\
\text { konsep fisika }\end{array}$ & 3,50 & Baik & tidak revisi \\
\hline $\begin{array}{l}\text { Bahasa dalam menjelaskan prosedur } \\
\text { pembuatan media pembelajaram }\end{array}$ & 3,25 & Cukup Baik & Ada revisi \\
\hline
\end{tabular}

Uji kelayakan (validasi dilakukan oleh 2 orang ahli yaitu ahli materi fisika dan ahli media. Uji kelayakan bertujuan untuk mengetahui kelayakan dari bahan ajar baik dari segi isi materi, penyajian yaitu tampilan bahan ajar, dan penggunaan bahasa di dalam bahan ajar. Hasil rata-rata uji kelayakan isi bahan ajar adalah 3,5 yang mempunyai kriteria baik dan tidah ada revisi. Hasil rata-rata uji kelayakan penyajian adalah 3,63 yang mempunyai kriteria baik dan tidak ada revisi. Hasil rata-rata uji kelayakan bahasa bahan ajar adalah 3,41 yang mempunyai kriteria baik. Terdapat masukan terkait penggunaan kata dalam kalimat terutama pada bagian prosedur pembuatan alar percobaan antara lain (1) terdapat beberapa kalimat yang masih membingungkan/ambigu, (2) terdapat beberapa huruf yang hilang dari kata, (3) terdapat beberapa rumus yang loncat dalam pengaturannya. Hasil rata-rata uji kelayan isi adalah 3,51 yang mempunyai kriteria baik, sehingga bahan ajar dikategorikan layak untuk digunakan.

2) Hasil Uji Coba Terbatas oleh Mahasiswa

Uji coba terbatas dilakukan pada Mahasiswa Pendidikan Fisika Universitas Kanjuruhan Malang angkatan 2016 sebanyak 25 mahasiswa. Ujicoba dilaksanakan dengan memberikan angket kepada mahasiswa. Data ujicoba terbatas terdiri dari data kuantitatif yang diperoleh dari nilai angket dan data kualitatif yang diperoleh dari masukan mahasiswa. Hasil analisis data uji coba disajikan pada Tabel 2. 
Tabel 2. Hasil Uji Coba Terbatas

\begin{tabular}{|c|c|c|c|c|}
\hline & Keterangan & Rata-rata & Kriteria & Kategori \\
\hline \multicolumn{5}{|c|}{ Aspek Tampilan Modul } \\
\hline 1 & Tulisan pada modul mudah dibaca & 3,55 & Baik & Tidak ada revisi \\
\hline 2 & Gambar yang disajikan menarik & 3,89 & Baik & Tidak ada revisi \\
\hline 3 & Cover modul menarik & 3,75 & Baik & Tidak ada revisi \\
\hline 4 & $\begin{array}{l}\text { Kombinasi warna yang digunakan } \\
\text { pada modul sesuai }\end{array}$ & 3,75 & Baik & Tidak ada revisi \\
\hline 5 & $\begin{array}{l}\text { Ada keterangan pada setiap } \\
\text { gambar }\end{array}$ & 3,10 & Cukup baik & Ada revisi \\
\hline \multicolumn{5}{|c|}{ Aspek penyajian materi } \\
\hline 1 & $\begin{array}{l}\text { Saya dapat memahami kalimat } \\
\text { pada modul ini }\end{array}$ & 3,75 & Baik & Tidak ada revisi \\
\hline 2 & $\begin{array}{l}\text { Saya dapat memahami symbol- } \\
\text { simbol yang terdapat pada modul }\end{array}$ & 3,35 & Baik & Tidak ada revisi \\
\hline 3 & $\begin{array}{l}\text { Penyajian materi pada modul } \\
\text { mudah saya pahami }\end{array}$ & 3,9 & Baik & Tidak ada revisi \\
\hline 4 & $\begin{array}{l}\text { penyajian langkah-langkah } \\
\text { pembuatan dan penggunaan } \\
\text { media pembelajaran mudah saya } \\
\text { pahami }\end{array}$ & 3,25 & Cukup Baik & Ada revisi \\
\hline
\end{tabular}

Data hasil uji coba/ uji keterbacaan terdiri dari dua komponen yaitu aspek tampilan modul dan aspek penyajian materi. Hasil rata-rata uji coba terbatas komponen tampilan modul adalah 3,61, dan hasil rata-rata komponen penyajian metrri adalah 3,56 dengan rata-rata total sebesar 3,58 yang mempunyai kategori baik, sehingga bahan ajar dikatakan layak untuk dipergunakan. Hasil ini sesuai pendapat Setiawan (2014) menyatakan bahwa bahan ajar modul dinyatakan berkualitas apabila semua aspek dalam instrumen penilaian buku mendapat "nilai" sangat baik dari semua aspek. Terdapat beberapa pendapat yaitu bahan ajar sudah baik dan jelas baik dalam penjelasan konsep dan penyajiannya karena disertai gambar-gambar yang digunakan sebagai pelengkap penjelasan atau kalimat. Pemakaian gambar akan memperjelas konsep-konsep yang bersifat abstrak. Hal ini sesuai pendapat Rosengrant, dkk (2009) yang menyatakan bahwa representasi gambar merupakan representasi yang kongkrit yang digunakan siswa untuk membangun persamaan matematik, menjelaskan konsep fisika dan sebagai acuan untuk menyelesaikan masalah yang lebih abstrak (Sundaygara, C., Kusairi, S., Hidayat, 2014). Akan tetapi terdapat beberapa masukan yang diberikan oleh mahasiswa pada uji coba terbatas antara lain (1) terdapat beberapa gambar pada prosedur pembuatan alat percobaan yang kurang jelas, (2) terdapat beberapa kalimat yang digunakan masih membingungkan atau belum baku, (3) terdapat beberapa kata yang hurufnya masih kurang, (4) terdapat beberapa gambar yang belum diberi keterangan.

\section{c) Revisi Bahan Ajar}

Revisi bahan ajar disasarkan pada saran dan masukan dari validator dan masukan atau saran dari mahasiswa pada saar ujicoba terbatas. Revisi yang dilakukan antara lain (1) memperbaiki tata bahasa dalam kalimat sehingga tidak membingungkan, (2) memperbaiki beberapa kata yang hurufnya kurang, (3) menuliskan kembali rumus-rumus fisika yang sesuai dengan konsep fisika, (4) memperbaiki gambar yang kurang jelas. 


\section{Simpulan}

Berdasarkan hasil analisis data dan pembahasan, maka kesimpulan dari penelitian ini adalah bahan ajar pengembangan media pembelajaran fisika berbasis multi representasi merupakan salah satu bahan ajar yang baik dan layak dipergunakan dalam proses pembelajaran. Hal ini didasarkan pada hasil validasi ahli dan ujicoba terbatas. Hasil rata-rata validasi ahli adalah 3,51 yang mempunyai kategori baik, sedangkan hasil ratarata ujicoba terbatas adalah 3,58 yang mempunyai kategori baik

\section{Daftar Rujukan}

Aji, S. D., Hudha, M. N., Huda, C., NANDIYANTO, A. B. D., \& ABDULLAH, A. G. (2018). the Improvement of Learning Effectiveness in the Lesson Study By Using E-Rubric. Journal of Engineering Science and Technology, 13(5), 1181-1189.

Arsyad, A. (2010). Media Pembelajaran. Jakarta: PT Raja Grafindo Persada.

Astuti, W. . (2012). Pengembangan Bahan Ajar Fisika SMA dengan Pendekatan Multi Representasi untuk Meningkatkan Pemahaman Konsep Siswa SMA Negeri 2 balikpapan. Malang.

Basyarudin Usman, M. dan A. (2002). Media Pembelajaran. Jakarta: Ciputat Pers.

De Cock, M. (2012). Representation use and strategy choice in physics problem solving. Physical Review Special Topics - Physics Education Research, 8(2), 1-15. https://doi.org/10.1103/PhysRevSTPER.8.020117

Gunawan. (2010). Model Pembelajaran Berbasis MMI untuk Meningkatkan Penguasaan Konsep Calon Guru pada Materi Elastisitas. Jurnal Penelitian Pendidikan, 2(1), 11-12.

Hudha, M. N., Aji, S. D., \& Huda, C. (2018). E-Rubric: Scientific Work Based on Android for Experimental Physic. IOP Conference Series: Materials Science and Engineering, 288(1). https://doi.org/10.1088/1757-899X/288/1/012100

Lovisa, U. (2011). Penggunaan Pendekatan Multi Representasi Pada pembelajaran Konsep Gerak Untuk Meningkatkan Pemahaman Konsep Siswa dan Memperkecil Miskonsepsi siswa SMP. Bandung.

Rosengrant, D., Van Heuvelen, A., \& Etkina, E. (2009). Do students use and understand free-body diagrams? Physical Review Special Topics - Physics Education Research, 5(1), 1-13. https://doi.org/10.1103/PhysRevSTPER.5.010108

Silaban, K.S., Bakri, S., Delina, M. (2016). Pengembangan Buku Berbasis Multi Representasi Seri Fluida dengan Pendekatan Sains Teknologi dan Masyarakat (STM). In Seminar Nasional Fisika 2016. Jakarta: Universitas Negeri Jakarta. https://doi.org/doi.org/10.21009/0305010208

Sobry Sutikno. (2013). Belajar dan Pembelajaran. Lombok: Holistica.

Stephens, A. L., \& Clement, J. J. (2010). Documenting the use of expert scientific reasoning processes by high school physics students, (November), 1-15. https://doi.org/10.1103/PhysRevSTPER.6.020122

Sundaygara, C., Kusairi, S., Hidayat, A. (2014). Pengaruh Multi Representasi pada Pembelajaran Berbasis Masalah terhadap Kemampuan Representasi Siswa SMA, 18, 37-42.

Sundaygara, C., \& Gaharin, D. (2017). PENGARUH MULTIPLE REPRESENTATION PADA PEMBELAJARAN BERBASIS MASALAH TERHADAP FISIKA, 1(2), 111-121.

Tytler, R., Haslam, F., Prain, V., \& Hubber, P. (2009). An Explicit Representational Focus for Teaching and Learning about Animals in the Environment. Teaching Science, 55(4), 21-27.

Utari, S. (2010). Pengembangan Program Perkuliahan untuk Membekali Calon Guru dalam Merencanakan Kegiatan Eksperimen Fisika di Sekolah Menengah. Bandung. 